\title{
KRAFT PULP AND CHEMICAL PROPERTIES OF CECROPIA PALMATA WOOD
}

\author{
Pupo CH${ }^{1}$, Calonego FW*, de Souza FML \& Sansígolo CA
}

São Paulo State University, School of Agriculture, Fazenda Experimental Lageado s/n, Botucatu, Brazil, 18610-034

fwcalonego@gmail.com

Submitted February 2019; accepted April 2019

\begin{abstract}
The present study was aimed at evaluating the chemical properties and the kraft pulp produced for Cecropia palmata wood and comparing them with Eucalyptus grandis wood. Discs along the stem of 6-year-old trees were transformed into chips. Half of the chips were used for characterisation of wood chemical properties and the rest was cooked to produce kraft pulp. The properties of the pulp were determined and results showed that: (1) there was a decrease of $3.8 \%$ in the yield of C. palmata pulp compared with E. grandis; (2) specific volume of C. palmata wood pulp increased with increasing refining time but the time to reach the same SchopperRiegler degree was shorter than E. grandis pulp; and (3) C. palmata had higher air resistance and tear index than E. grandis, while the opposite was observed for tensile index, burst index and stretch. Cecropia palmata wood had lower lignin content and higher total extractives and holocellulose contents than E. grandis wood.
\end{abstract}

Keywords: Imbaúba, pulp properties, pulp yield, fibre, chemical compounds

\section{INTRODUCTION}

Cecropia palmata (imbaúba) is a pioneer plant species native to Brazil and has high potential for ecological restoration projects in the Amazonian Forest (Antongiovanni \& Metzger 2005, Zeller et al. 2013). This species presents fast-growing trees, high basal area and is one the most frequent species in secondary forests (Rodrigues et al. 2007). Its wood is used for making low-density particleboards, charcoal and paper.

In general, the heterogeneity of wood causes a great deal of inconvenience mainly to the furniture, wood and pulp and paper industries. Chemical, physical and anatomical variations in the wood change the yield and quality of the pulp and the paper (Forsström et al. 2005, Sansígolo \& Ramos 2011, Santos et al. 2012, Severo et al. 2013). Variations in pulp properties of low and high density woods are due to fibre coarseness (Santos \& Sansígolo 2007, Magaton et al. 2009). Longer fibre lengths and higher fines content of wood with high density positively influence the mechanical properties of pulp (Myers et al. 1996, Santos \& Sansígolo 2007). Yield and tear index of pulp from mature wood of Populus tremuloides are higher than that of juvenile wood (Myers et al. 1996) but the opposite was observed in Pinus contorta (Hatton \& Gee 1994).
Although various studies have been conducted on pulping of several softwood and hardwood, there is little knowledge on pulping of new potential species. Thus, the present study was aimed at evaluating the chemical properties and the kraft pulp produced from C. palmata wood and comparing it with those from Eucalyptus grandis wood.

\section{MATERIALS AND METHODS}

\section{Collection of materials}

This study utilised the wood of 10 trees from 6-year-old C. palmata from a naturally-grown forest located in Peixoto de Azevedo-Mato Grosso State $\left(10^{\circ} 21^{\prime} \mathrm{S}, 54^{\circ} 19^{\prime} \mathrm{W}\right)$, Brazil, as well as 10 trees from 6-year-old Eucalyptus grandis from the reforested area managed by the Lwarcel Company located in Cabrália Paulista, São Paulo State $\left(22^{\circ} 27^{\prime} \mathrm{S}, 49^{\circ} 20^{\prime} \mathrm{W}\right)$, Brazil. Trees were felled and 30-mm thick discs were sectioned in the stem with a chainsaw. The first disc was sectioned at the base and the others at 25, 50, 75 and $100 \%$ up to commercial height (diameter of $8 \mathrm{~cm}$ ). Each disc was subdivided into $90^{\circ}$ wedges. One wedge from each disc of each tree was used 
to determine the basic density (ratio between the oven-dry mass and saturated volume) (ABCP M14 1970), and the rest of the wedges were used for determination of chemical and anatomical properties and kraft pulping.

\section{Chemical and anatomical properties of woods}

Two wedges from each disc of each tree were manually turned into chips using a machete and hammer. Chips from discs of the same tree were grouped into composite samples, which represented each tree that was studied. A portion of the chips was processed into sawdust of between 40 and 60 mesh using a cutting mill. Total extractives content was determined by extraction sequences with ethanol/toluene 1/2 (v/v), ethanol and hot water (TAPPI T 12 wd-82 1999). The acid-insoluble Klason lignin (TAPPI T 13 wd-74 1999) and holocellulose contents (ASTM D-1104 1978) were determined in extractive-free wood.

Morphologic analysis of fibres from C. palmata, as well as E. grandis was performed using fibre quality analyser. The analyser measured the dimensions of 20,000 fibres and gave the average values (fibre length, fibre width, fibre coarseness and fibre population, i.e. fibres per mass unit) that represented the compound samples.

\section{Kraft pulping of wood}

Kraft pulping of C. palmata and E. grandis wood was performed using a digester. The following kraft cooking conditions were used: active alkali as $\mathrm{Na}_{2} \mathrm{O}$ of $16 \%$ oven-dry wood, $0.05 \%$ anthraquinone, $25 \%$ sulfidity, maximum cooking temperature of $170{ }^{\circ} \mathrm{C}$, time up to target a maximum temperature of $90 \mathrm{~min}$, cooking time at maximum temperature of $30 \mathrm{~min}$, and liquor-to-wood ratio of $3.8 \mathrm{~L} \mathrm{~kg}^{-1}$. Subsequently, the pulps were washed, screened and processed using fibre sorter equipped with a $0.2-\mathrm{mm}$ slot screen.

\section{Refining and physic-mechanical properties of kraft pulp}

Samples of each kraft pulp were beaten in a mill at $4500,6750,9000,11,250$ and 13,500 revolutions $\mathrm{min}^{-1}$. The refining degree was determined using Schopper-Riegler method (SCAN M3:65 1980). Handsheets, each weighing $60 \mathrm{~g} \mathrm{~m}^{-2}$, were made in a Rapid-Köthen sheet former for the physico-mechanical tests, and placed in a climatic chamber adjusted to $23 \pm$ $2{ }^{\circ} \mathrm{C}$ and $50 \pm 2 \%$ relative humidity, according to the standards presented in TAPPI T 402 om93 (1999). The following physico-mechanical properties were evaluated: specific volume (TAPPI T 220 sp-96 1999), tensile properties (TAPPI T 494 om-96 1999), burst index (TAPPI $\mathrm{T} 403$ om-97 1999), tear index (TAPPI T 414 om-98 1999), and air resistance (TAPPI T 460 om-96 1999). The relationship between each physico-mechanical property and the SchopperRiegler degree ( $\left.{ }^{\circ} \mathrm{SR}\right)$ was evaluated using linear and polynomial regression by taking into account the observed tendency of data.

\section{RESULTS AND DISCUSSION}

\section{Chemical and anatomical properties of wood}

Table 1 shows that the total extractives, lignin and holocellulose contents of C. palmata wood are $4.05,20.81$ and $76.51 \%$ respectively, and these respective compounds in E. grandis wood are 2.68, 24.03, and 73.29\%. Morphologic analyses of fibres of C. palmata and E. grandis wood are tabulated in Table 2. Average fibre lengths of the two species were 1.289 and $0.832 \mathrm{~mm}$ and fibre widths were 26.37 and $18.53 \mathrm{~mm}$. Fibre coarseness of both species were 23.55 and $13.23 \mathrm{mg} 100 \mathrm{~m}^{-1}$ respectively, while fibre population values in the pulp were 5.7 and 12.1 mil fibre $\mathrm{g}^{-1}$ respectively. These results are similar to those of hardwood (Fengel \& Wegener 1989), some eucalypts (e.g. Severo et al. 2013) and C. palmata (Paula 2003). The values of C. palmata wood are similar to values of other common species used in pulping industries, so this Amazonian species has potential to the proposed use.

\section{Kraft pulping of woods}

Total and screened pulp yield values of $C$. palmata wood were smaller (up to $3.8 \%$ ) than that of E. grandis wood (Table 3). The reject rate based on wood and pulp used of both species were not significantly different.

Low basic density and holocellulose content and high lignin and total extractives contents 
Table 1 Chemical properties of Cecropia palmata and Eucalyptus grandis wood

\begin{tabular}{|c|c|c|c|c|c|c|}
\hline \multirow[t]{2}{*}{ Property } & \multirow[t]{2}{*}{$\mathrm{N}$} & \multicolumn{2}{|c|}{ E. grandis } & \multicolumn{2}{|c|}{ C. palmata } & \multirow{2}{*}{$\begin{array}{l}\text { Reduction or } \\
\text { (increase) \% }\end{array}$} \\
\hline & & $\mathrm{CV}$ & Mean & $\mathrm{CV}$ & Mean & \\
\hline Total extractives content, $\%$ & 10 & 22.69 & 2.68 & 12.85 & 4.05 & $(51.1)^{*}$ \\
\hline Klason lignin content, \% & 10 & 5.34 & 24.03 & 4.91 & 20.81 & $13.4^{*}$ \\
\hline Holoceluloses content, \% & 10 & 2.16 & 73.29 & 2.33 & 76.51 & $(4.4) *$ \\
\hline
\end{tabular}

$\mathrm{N}=$ repeat number of trees, $\mathrm{CV}=$ coefficient of variation, * = significant difference by $\mathrm{F}$ test at probability $95 \%$

Table 2 Morphologic analysis of fibres and basic density of Cecropia palmata and Eucalyptus grandis wood

\begin{tabular}{|c|c|c|c|c|c|c|}
\hline \multirow[t]{2}{*}{ Property } & \multirow[t]{2}{*}{$\mathrm{N}$} & \multicolumn{2}{|c|}{ E. grandis } & \multicolumn{2}{|c|}{ C. palmata } & \multirow{2}{*}{$\begin{array}{l}\text { Reduction or } \\
\text { (increase) } \%\end{array}$} \\
\hline & & $\mathrm{CV}$ & Mean & $\mathrm{CV}$ & Mean & \\
\hline Fiber length (mm) & 10 & n.d. & 0.832 & n.d. & 1.289 & $(54.9)$ \\
\hline Fiber width (mm) & 10 & n.d. & 18.53 & n.d. & 26.37 & $(42.3)$ \\
\hline Fiber coarseness $\left(\mathrm{mg} 100 \mathrm{~m}^{-1}\right)$ & 10 & n.d. & 13.23 & n.d. & 23.55 & $(78.0)$ \\
\hline $\begin{array}{l}\text { Fiber population (millions of } \\
\text { fibers } \mathrm{g}^{-1} \text { ) }\end{array}$ & 10 & n.d. & 12.1 & n.d. & 5.7 & 52.9 \\
\hline Fines fraction $(\%)$ & 10 & n.d. & 1.27 & n.d. & 3.70 & (191.3) \\
\hline Basic density $\left(\mathrm{g} \mathrm{cm}^{-3}\right)$ & 10 & 6.09 & 0.455 & 14.31 & 0.389 & $14.5^{*}$ \\
\hline
\end{tabular}

$\mathrm{N}=$ repeat number of trees, $\mathrm{CV}=$ coefficient of variation, n.d. = not determined because composite samples by 20,000 fibres were measured, * = significant difference by $\mathrm{F}$ test at probability $95 \%$

Table 3 Kraft pulping of Cecropia palmata and Eucalyptus grandis wood

\begin{tabular}{|c|c|c|c|c|c|c|}
\hline \multirow[t]{2}{*}{ Property } & \multirow[t]{2}{*}{$\mathrm{N}$} & \multicolumn{2}{|c|}{ E. grandis } & \multicolumn{2}{|c|}{ C. palmata } & \multirow{2}{*}{$\begin{array}{l}\text { Reduction or } \\
\text { (increase) } \%\end{array}$} \\
\hline & & CV & Mean & $\mathrm{CV}$ & Mean & \\
\hline $\begin{array}{l}\text { Total pulp yield, \% oven-dry } \\
\text { wood }\end{array}$ & 10 & 3.52 & 52.26 & 4.46 & 50.28 & $3.8^{*}$ \\
\hline $\begin{array}{l}\text { Screened pulp yield, } \% \text { oven- } \\
\text { dry wood }\end{array}$ & 10 & 3.12 & 51.70 & 3.85 & 49.89 & $3.5^{*}$ \\
\hline Reject rate, $\%$ oven-dry wood & 10 & 66.28 & 0.56 & 181.11 & 0.39 & $30.4^{\mathrm{NS}}$ \\
\hline Reject rate, $\%$ oven-dry pulp & 10 & 63.28 & 1.07 & 176.40 & 0.75 & $29.9^{\mathrm{NS}}$ \\
\hline $\begin{array}{l}\text { Wood consumption, } \mathrm{m}^{3} / \mathrm{t} \\
\text { oven-dry pulp }\end{array}$ & 10 & 7.03 & 4.27 & 15.39 & 5.26 & $23.2 *$ \\
\hline Kappa number & 10 & 12.27 & 19.1 & 26.86 & 18.2 & $4.7^{\mathrm{NS}}$ \\
\hline
\end{tabular}

$\mathrm{N}=$ repeat number of trees, $\mathrm{CV}=$ coefficient of variation, $*=$ significant difference by $\mathrm{F}$ test at probability $95 \%$, NS $=$ nonsignificant difference

reduce wood pulping yield and increase the rejects produced during pulping (Magaton et al. 2009, Sansígolo \& Ramos 2011, Santos et al. 2012). Thus, as seen in Table 1 , the higher total extractives content of C. palmata compared with E. grandis wood can explain its lower pulp yield and reject rate obtained during pulping process.
In addition, the lignin structure (syringyl/ guaiacyl ratio), the higher total extractives content and the lower basic density of wood have been considered as the main causes of this variability (Santos et al. 2012). Thus the structure of lignin from C. palmata should be studied in future studies. 
Physico-mechanical properties of the kraft pulps

The physico-mechanical properties of the kraft pulps from C. palmata and E. grandis wood are shown in Figures 1 and 2 in the form of the Schopper-Riegler degree. Kraft pulp from C. palmata wood required shorter refining revolution and, consequently, shorter refining time compared with pulp from E. grandis to reach the same Schopper-Riegler degree. This effect may be explained by the difference in basic density between C. palmata $\left(0.389 \mathrm{~g} \mathrm{~cm}^{-3}\right)$ and E. grandis wood $\left(0.455 \mathrm{~g} \mathrm{~cm}^{-3}\right)$. Similar results were shown by Hatton and Gee (1994) and Santos and Sansígolo (2007).

Kraft pulp from E. grandis wood produced sheets with lower specific volume than pulp from C. palmata wood at the highest refining levels (Figure 1b). Similar results were reported by Hatton and Gee (1994), Forsström et al. (2005) and Santos and Sansígolo (2007) for pulps of Pinus contorta, Picea $\mathrm{sp}$. and E. urophylla $\times$ grandis respectively. This effect on sheets specific
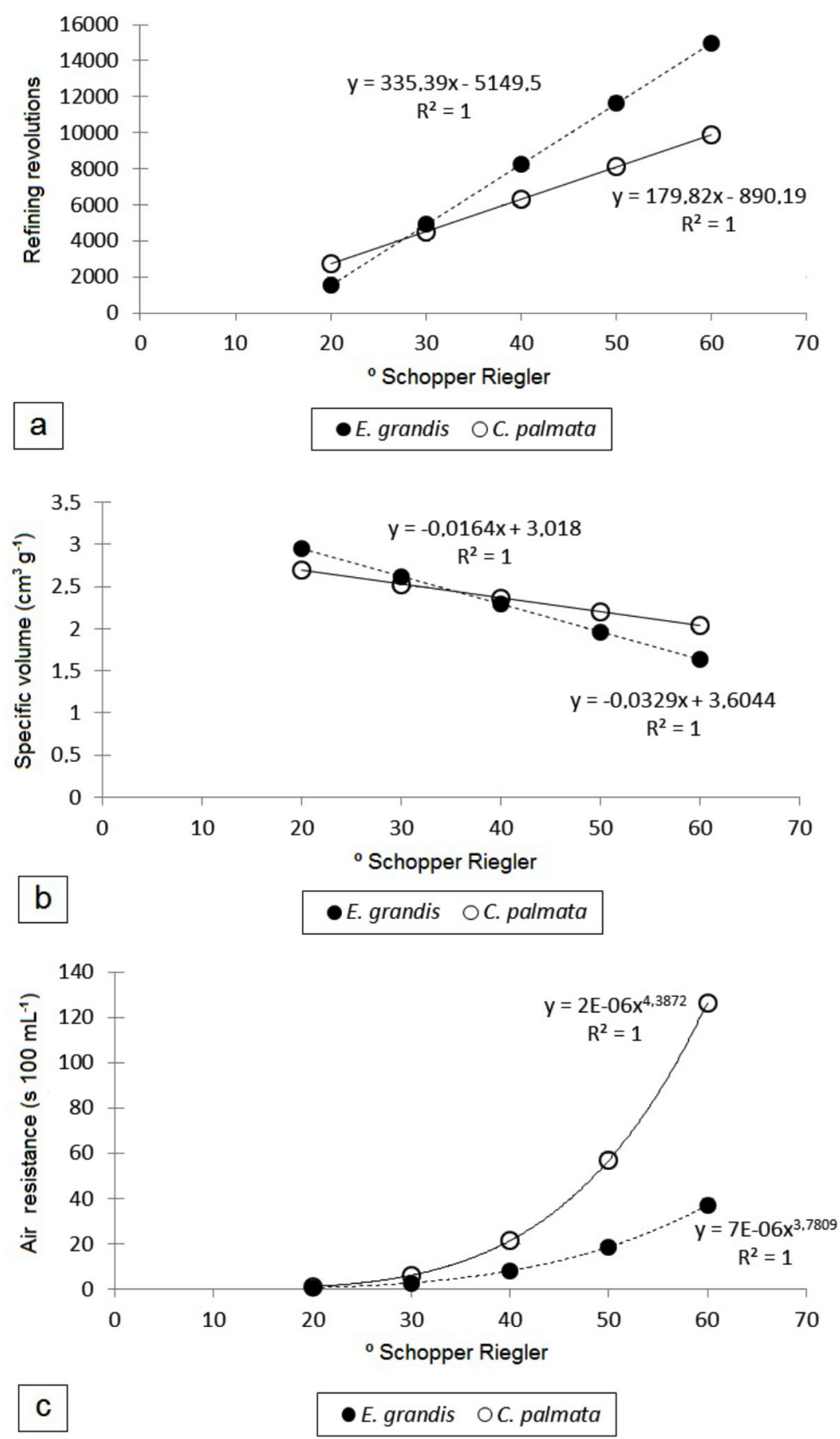

Figure 1 Physical properties and air resistance of kraft pulp from Cecropia palmata and Eucalyptus grandis 

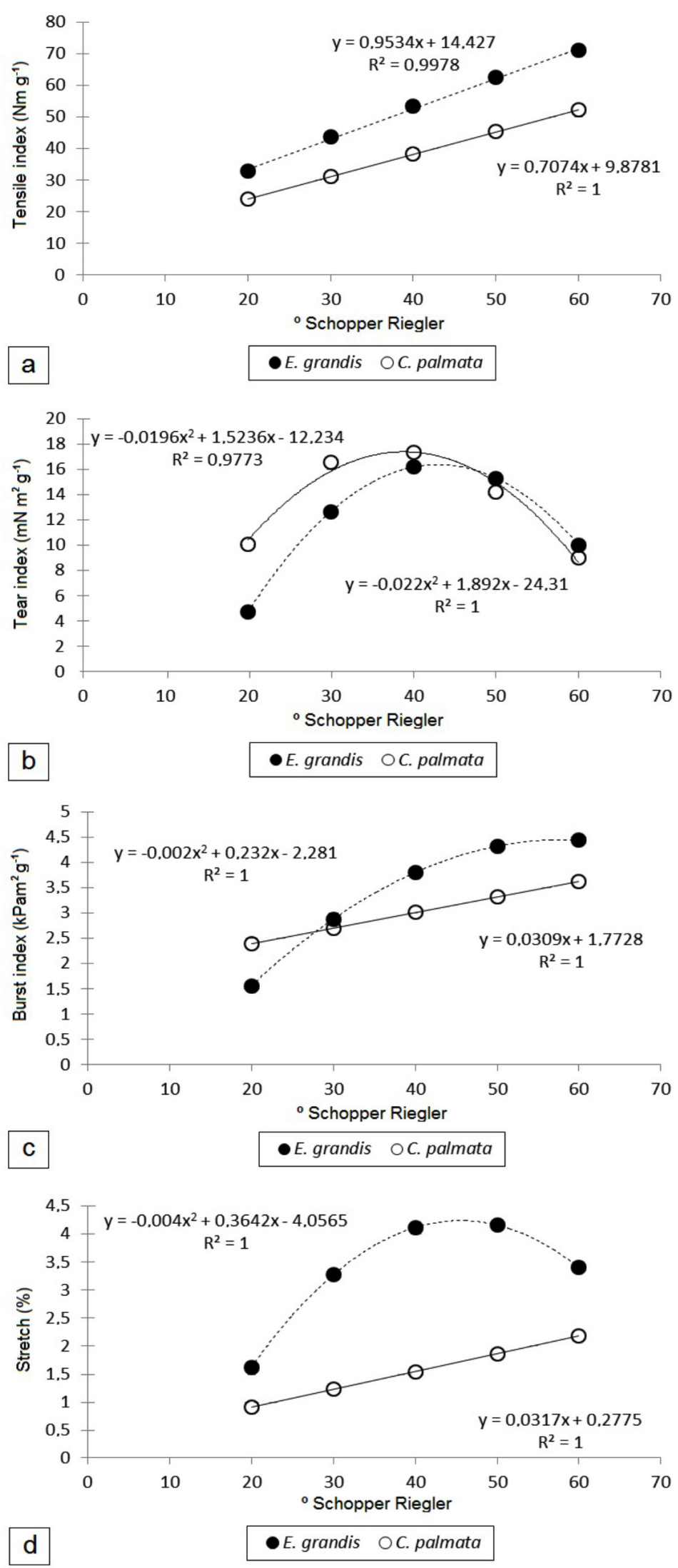

Figure 2 Mechanical properties of kraft pulp from Cecropia palmata and Eucalyptus grandis 
volume may be explained by the difference in coarseness (see Table 2) between C. palmata $\left(23.55 \mathrm{mg} 100 \mathrm{~m}^{-1}\right)$ and Eucalyptus wood (13.25 mg $100 \mathrm{~m}^{-1}$ ). Wood fibres with low coarseness produce pulp with high consolidation among the fibres (Forsström et al. 2005).

Refined pulp of C. palmata had similar air resistance as E. grandis pulp until 30 SchopperRiegler degree but increased thereafter (Figure 1c). Longer and wider fibres in C. palmata wood pulp with an increase in the SchopperRiegler degree can be associated with higher fines fractions produced at the higher levels of refining (Santos \& Sansígolo 2007). Low levels of refining and good air resistance of $E$. grandis wood pulp are due to strong interfibre bonding. This bonding is due to the lower coarseness of these fibres (Hatton \& Gee 1994, Forsström et al. 2005). In this present study, fines fraction of $C$. palmata was $3.70 \%$, while in E. grandis it was $1.27 \%$ (Table 2). The fines fraction, also called fines content, is an important property for pulping of wood species. The higher the fines content the lower the pulping yield.

Kraft pulp from C. palmata had lower tensile index, tear index and stretch compared with $E$. grandisfor all levels of the Schopper-Riegler degree (Figure 2). This shows that the higher the basic density, the higher the mechanical resistance of kraft pulps. (Hatton \& Gee 1994, Forsström et al. 2005, Myers et al. 1996, Santos \& Sansígolo 2007). Eulalyptus grandis pulp had lower tear index than C. palmata wood at the smallest Schopper-Riegler degree. However, at 40 Schopper-Riegler degree the pulps showed opposite behaviour showing that high levels of refining produce high fines fraction. Although lower fibre coarseness of wood improved interfibre bonding (Hatton \& Gee 1994, Forsström et al. 2005), increased refining level produced higher fines fractions in E. grandis wood, and the tear index values of this pulp were similar to those presented by the C. palmata wood pulp. In general, the pulps that produced paper with higher tensile strength (Figure 2a) also produced stiffer sheets. However, interfibre bonding, chemical properties and refining time can change this relationship.

\section{CONGLUSIONS}

Cecropia palmata wood had lower lignin content and higher total extractives and holocellulose contents than E. grandis wood. Through kraft pulping of C. palmata, it was concluded that: (1) there was a decrease of $3.8 \%$ in the total pulp yields compared with $E$. grandis wood; (2) this wood pulp had higher specific volume with increasing refining time and required a shorter refining time than the pulping of $E$. grandis wood to reach the same Schopper-Riegler degree; and (3) this wood pulp had higher air resistance and tear index than $E$. grandis, while the opposite was observed for pulp tensile index, burst index and stretch.

\section{ACKNOWLEDGMENT}

The authors thank the Coordinator for the Improvement of Higher Level Personnel, Brazil, for financial support.

\section{REFERENGES}

ABCP M14. 1970. Basic Density of Wood. Associação Brasileira de Celulose e Papel, São Paulo.

Antongiovanni M \& Metzger JP. 2005. Influence of matrix habitats on the occurrence of insectivorous bird species in Amazonian forest fragments. Biological Conservation 122: 441-451. https://doi. org/10.1016/j.biocon.2004.09.005.

ASTM D-1104. 1978. Standard Method for Holocellulose in Wood. American Society for Testing and Materials International, West Conshohocken.

Fengel D \& Wegener G. 1989. Wood: Chemistry, Ultrastructure, Reactions. Gruyter, New York.

Forsström J, Torgnysdotter A \& Wagberg L. 2005. Influence of fibre/fibre joint strength and fibre flexibility on the strength of papers from unbleached kraft fibres. Nordic Pulp Paper Research Journal 20: 186-191. https://doi.org/10.3183/npprj-2005-2002-p186-191.

Hatton JV \& GeE WY. 1994. Kraft pulping of second-growth lodgepole pine. Tappi Journal 77: 91-102.

Magaton ADAS, Colodette JL, Gouvêa AFG, Gomide JL, Muguet MCS \& Pedrazzi C. 2009. Eucalytus wood quality and its impact on kraft pulp production and use. Tappi Journal 8: 32-39.

Myers GC, Arola RA, Horn RA \& Wegner TH. 1996. Chemical and mechanical pulping of aspen chunkwood, mature wood, and juvenile wood. Tappi Journal 79: 161-168

PAUla JE. 2003. Caracterização anatômica da madeira de sete espécies da Amazônia com vistas à produção de energia e papel. Acta Amazonica 33: 243-262.

Rodrigues MACM, Miranda IS \& Kato MSA. 2007. Estruturas de florestas secundárias após dois diferentes sistemas agrícolas no nordeste do estado do Pará, Amazônia Oriental. Acta Amazonica 37: 591-598. http:/ /dx.doi. org/10.1590/S0044-59672007000400014.

Sansígolo CA \& Ramos ES. 2011. Quality of wood and pulp from a clone of Eucalyptus grandis planted at three locations. Cerne 17: 47-60. http://dx.doi. org/10.1590/S0104-77602011000100006. 
Santos A, Anjos O, Amaral ME, Gil N, Pereira H \& Simões R. 2012. Influence on pulping yield and pulp properties of wood density of Acacia melanoxylon. Journal of Wood Science 58: 479-486. https://doi.org/10.1007/ s10086-012-1286-2.

SANTOS SR \& SAnsígolo CA. 2007. Influência da densidade básica da madeira de clones de Eucalyptus grandis $\times$ urophylla na qualidade da polpa branqueada. Ciência Florestal 17: 53-63. http://dx.doi. org/10.5902/198050981935.

SCAN M3:65. 1980. Drainability by the Schopper-Riegler Method. Scandinavian Pulp, Paper and Board, Stockholm.

Severo ETD, Sansígolo CA, Calonego FW \& Barreiros RM. 2013. Kraft pulp from juvenile and mature woods of Corymbia citriodora. Bioresources 8: 1657-1664

TAPPI T 12 wd-82. 1999. Preparation of Wood for Chemical Analysis. Technical Association of the Pulp and Paper Industry, Atlanta.

TAPPI T 13 wd-74. 1999. Lignin in Wood. Technical Association of the Pulp and Paper Industry, Atlanta.

TAPPI T 220 sp-96. 1999. Physical Testing of Pulp Handsheets. Technical Association of the Pulp and Paper Industry, Atlanta.
TAPPI T 402 om-93. 1999. Standard Conditioning and Testing Atmospheres for Paper, Board, Pulp Handsheets and Related Products. Technical Association of the Pulp and Paper Industry, Atlanta.

TAPPI T 403 om-97. 1999. Bursting Strength of Paper. Technical Association of the Pulp and Paper Industry, Atlanta.

TAPPI T 414 om-98. 1999. Internal Tearing Resistance of Paper. Technical Association of the Pulp and Paper Industry, Atlanta.

TAPPI T 460 om-96. 1999. Air Resistance of Paper. Technical Association of the Pulp and Paper Industry, Atlanta.

TAPPI T 494 om-96. 1999. Tensile Properties of Paper and Paperboard. Technical Association of the Pulp and Paper Industry, Atlanta.

Zeller F, Barbu MC \& Iwakiri S. 2013. Paricá (Schizolobium amazonicum) and Embaúba (Cecropia sp.) as new raw materials for particleboards. European Journal of Wood and Wood Products 71: 823-825. https://doi. org/10.1007/s00107-013-0725-0. 